\title{
The marketing-sales organizations as the way of internationalizing of the small and medium enterprises
}

Joanna Piorunowska-Kokoszko, Ph.D. University of Lodz Faculty of Management Logistics Departmen

\section{Introduction}

Contemporary enterprises permanently seek the best development strategies which allow them to increase their market share, profits and generate benefit for shareholders. One of such solution is market development that is an internationalization strategy. Making such a decision to enter new markets enterprises take a risk, but also can expect adequate benefits, that is the ones that are higher than those they can win on the domestic market. Moreover, in global economy the internationalization trend results from an increasingly higher number of competitors from different parts of the world, which, in turn, spurs them to seek the most effective solutions, including the cheapest sources of goods (Nieżurawski 2010, pp. 198211). However, for an enterprise, it not only hard to internationalize its activities but also maintain it in such a form. The first decade of the 21st century showed that world of business more and more often bowed to the need of establishing long-term cooperation, because modern economy requires it (Nowak 2012, p. 5). A wide range of benefits of such a mode of cooperation encourages market 
participants to start close collaboration by means of building organizational closeness. Cooperation, i.e. taking joint action/working in harmony by different sorts of business entities is becoming an indispensable element of contemporary world economy (Czakon 2010, p. 18), while the cooperating parts can be both individuals as well as their groups or large scale organizations. Of course, business enterprises cooperate as well, taking joint actions resulting from their voluntary establishment of close relations, being characterized by their attainment of both common and individual goals. (Mazur 2011, pp. 290291). Also the present crisis gives a special stimulus to cooperative reports, because the very fact of establishing cooperation can turn out to be a way of surviving the difficult times. A trend towards cooperation is discernible in a cornucopia of modern national economies, and takes on a number of forms, having become an important factor shaping the future of small and medium enterprises (SME). Lichtarski listed three levels of co-operation, starting from mere regular collaboration between the supplier and the buyer, while continuing up to the level of establishing collaborative coordination-distribution centers of varied structures, i. e. syndicates or associations. (Lichtarski 2007, pp. 420445). A marketing-sale cooperative organization which includes legally independent enterprises is an innovative variety of such. The main aim of this article is to outline principles of marketing-sale group activities as well as demonstrating that such a form of cooperation is one of currently available ways of market development for Polish small and medium enterprises, since it enables them to intensify their export in a relatively short time, and optimizing costs of this undertaking at the same time. The data collected in this article are based on literature study and report of research institutions dealing with the set problem.

\section{Polish small and medium enterprises activity in foreign markets and their perspective of market development}

The European Commission defined a medium-sized enterprise as one employing fewer than 250 employees, and whose annual turnover does not exceed 50 million euro, and/or whose complete annual balance sheet does not exceed 43 million euro. In turn, a small company employs fewer than 50 employees, and has an annual turnover and/or the complete annual balance sheet below 10 million euro. (Regulation of the European Commission of No. 651 / 2014 from 17 June 2014). Small and medium-sized enterprises (SME) constitute, according to P. Drucker, "salt of the market economy" (Drucker 2002, 
p. 17) which means, that their market forces have a special, and exceptional potential. According to the data collected by the Eurostat (www.parp.gov. $\mathrm{pl}$ ), the participation of the SME sector in the GDP in Poland is only a little bit smaller than the average characteristic of the countries of the European Union (48.3\%). SME companies conduct their activities not only in their native country, but also successfully try to enter foreign markets. Data of the Polish Central Statistical Office concerning the year 2014 shows that, over the period, Polish enterprises sold goods and services abroad for the over $682 \mathrm{~m}$ PLN and that their 2014 export total experienced a growth of 5.4\% in comparison to the year 2013, while small and medium-sized companies are credited to have had a significant contribution to this trend (www.gus.pl). Report of the Institute of the Market Economy Research Leviathan (Wyżnikiewicz 2013, p. 21) shows that, on the one hand, the small scale of its activity lets the SME sector maintain flexibility, but on the other hand, it limits its bargaining power in respect to their collaboration with large companies. Such a situation has had its impact on, for instance, export financing conditions, which is clearly visible in the fact that, according to the Bibby Financial Service report, as many as $15 \%$ of Polish small suppliers are forced to allow their large customers a payment deadline between 60 and 90 days. As a result, small Polish firms have been "bullied" to finance large foreign companies (www.poland-export.pl/articles/3983). In spite of such situations, foreign expansion of Polish SME more and more often turns out to be an essential factor contributing to an increase in the added value of the firm, and a consistent growth in Polish export. Since the beginning of the transformation, i.e. since 1991 value of the goods sold abroad has grown fourteen times, and since joining the European Union in 2004 it has risen 2.6 - times. It could seem that such an effect is satisfying, however, compared with other countries, Poland does not turn out to be the leader. The Eurostat shows that the scale of operations of Polish enterprises in foreign markets is still insufficient. Only 3.4\% of those companies sell products and services inside the EU, and only $1.7 \%$ of those send their products to other countries of world (which result places Poland in the last positions amongst EU countries). In case of small and medium enterprises this percentage is even smaller (Niewinowska, 2015, p. 10). The insufficient SME's activity on the international arena leads to the fact that their potential remains untapped, which, of course, has had an adverse impact on both their competitiveness as well as the Polish economy in general (Gajowiak 2014, p. 109). According to PARP's data of 2015, 40 thousand Polish SME i.e. the $8 \%$ is interested in foreign expansion, however about the $60 \%$ of them does not conduct any permanent activities on foreign markets. The European Commission report shows that the main factors which

The marketing-sales organizations as the way of internationalizing of the small and medium enterprises 
impede the development of export are: the lack of command of foreign languages, cultural differences, adversities of legal (or administrative) procedures, different consumption patterns, and differences in the mechanisms of business running. Hence, over the $65 \%$ of European SME interested in export expect a support and consulting in this area (www.biznes.pl/firma/eksperci-male-i-srednie-firmywymagaja-wsparcia-by-zawojowac-swiat/th5r7h). Polish companies which want to develop their businesses and expand into international markets, are, on the one hand, left to their own devices, but on the other, can count on comprehensive financial support from the European fund resource, in which 630 billion euro is dedicated to support export activities in the years 2014-2020. The offered support corresponds directly to trends on the global market, which shows the need for supporting SME in establishing international cooperation and in their marketing strategy development and implementation. Additionally, financial support is directed at Domestic Clusters, that is those ones, which have a high priority for the Polish economy. The funds are designed to support all SME initiatives to build cooperation structures contributing to their growth on international markets and an increase in their competitiveness. (Niewinowska 2015, p. 11). It should be borne in mind that creating marketing-sale organizations is one of such solutions.

\section{Marketing-sale organizations as example of cooperation}

The literature defines the marketing-sale organizations (also known as producers sales organizations - PSO, or independent sales organizations - ISO) as an association, or a consortium of firms which sale their products in order to use the economies of scale effect, build a strong position in negotiations and obtain better trade conditions (Wilson 2005, p. 17). This cooperation allows to keep competitive strength of the large supplier at preserving the concentration on crucial competence and reduce costs of transactions for SME (Wrońska 2012, p. 142). Sales organizations usually act only in the B2B sector. They often emerge from varied marketing alliances, because the latter are supposed to lead to marketing joint actions visible enough to be noticed by target groups (Aluchna, Cygler et al. 2011, p. 152). Firstly, sales organizations, providing access to a wide range of products and resources of all their members, faster build their selling power on the market. Additionally, they can develop selling power to the needs of a corporation, a sector or even to the scale of an interpectoral activity, combining different company from different sectors (Kaszyński, Fedorowski 2011, p. 67). Moreover, marketingsales organizations, having accumulated negotiating power more quickly, tend to achieve a better effect of favorable conditions of transaction than in the case 
of an individual company, which is reflected in such indicators as better selling prices, better conditions of service, and standardization of the assortment. Apart from measurable economic conditions of the scale, a sales organization's members can get other benefits, such as transfer of knowledge or innovation (Bartkowiak, Domański 2012, p. 15). Mention above thestes are proved by the research of automobile sector in the USA, which shows the $19 \%$ growth of sales made by sales group organizations. Arlena Sawyers (2015), Big, medium-sized dealership groups grow, Automative News, Suplement, 16 marca 2015, www.autonews.com/assets/ PDF/CA98762313.PDF dostęp: 27.10.2016.

There are several marketing-sales organization models, which are singled out according to different criteria. The first criterion is product itself, the other is the area of interest, the third is the market segment, while the fourth is a combination of at least two of the afore-mentioned.

- Organization by product - the model is singled out on the basis of the offered assortment; accordingly, in each of the product groups, there are products which are the same or similar (figure 1) [Spaho 2010, pp. 411-413].

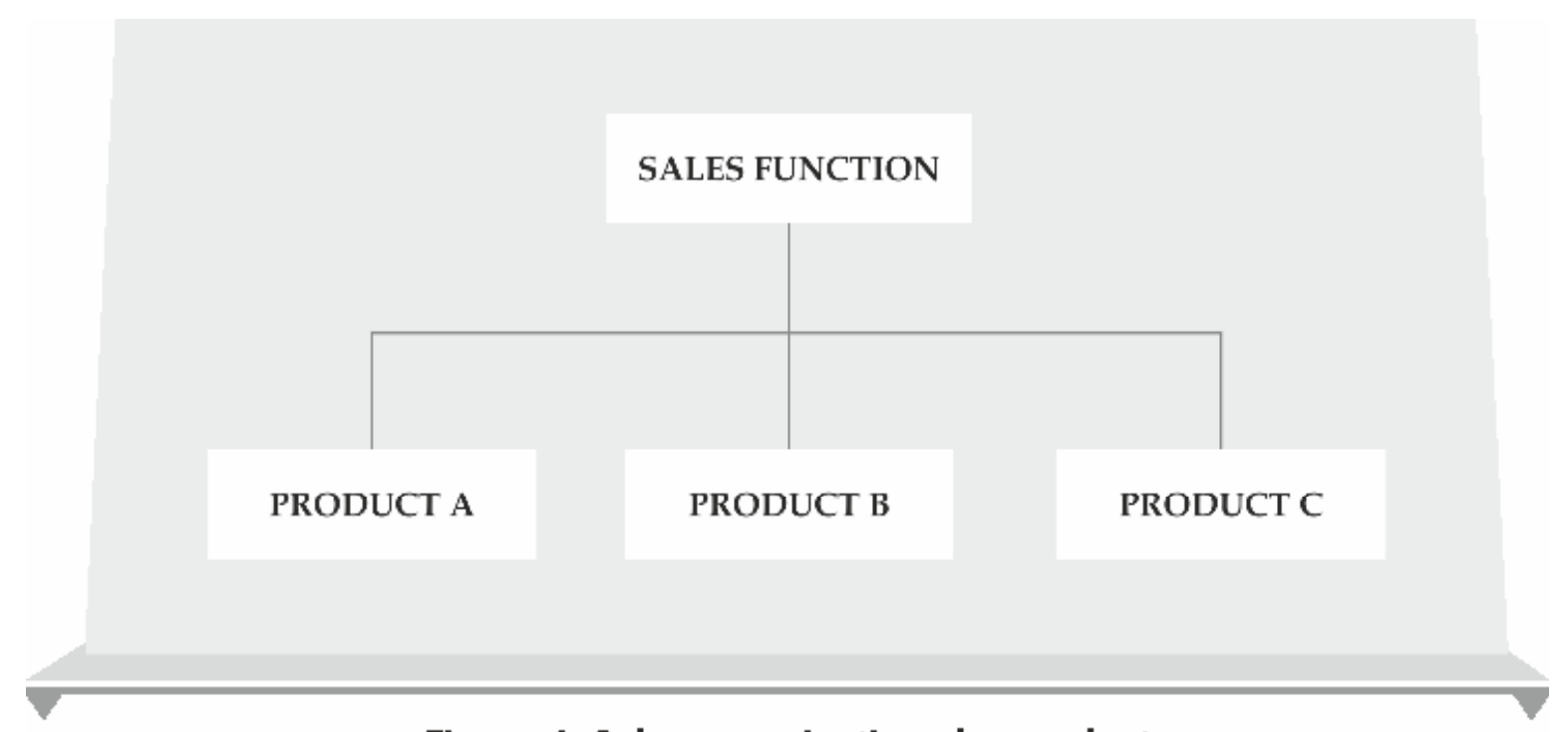

Figure 1. Sales organizations by product

Source: Spaho K., Sales organization and functionality in companies on the industrial market in Bosnia and Herzegovina management research and practice Vol. 2, Iss. 4 (2010), p. 411

- Organization by territory - is based on dividing sales function by territory where the organization sells products of its member- it is presented in figure 2

The marketing-sales organizations as the way of internationalizing of the small and medium enterprises 


\section{SALES FUNCTION}

REGION A

REGION B

REGION C

\section{Figure 2. Sales organizations by territory}

Source: Spaho K., Sales organization and functionality in companies on the industrial market in Bosnia and Herzegovina management research and practice Vol. 2, Iss. 4 (2010), p. 411

- Organization by market - is based on sales organization by market segments. Market segments can be constituted by manufacturers, wholesalers, retailers, big consumers, small shops etc. as it is presented in figure 3.

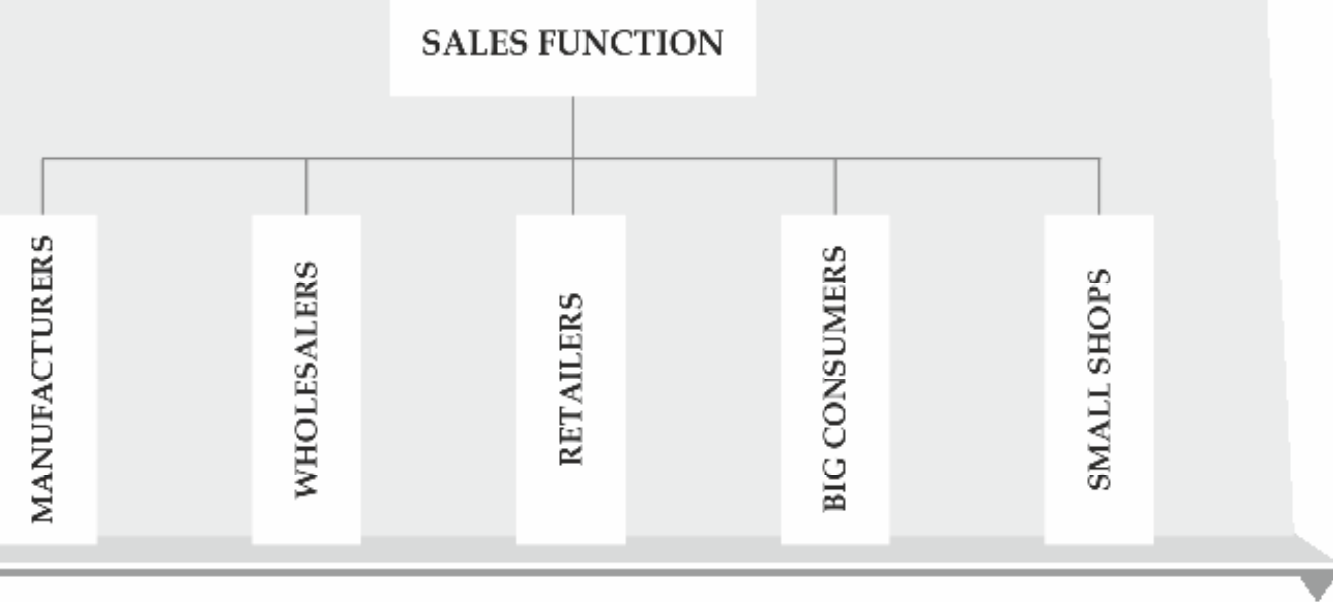

Figure 3. Sales organizations by market

Source: Spaho K., Sales organization and functionality in companies on the industrial market in Bosnia and Herzegovina management research and practice Vol. 2, Iss. 4 (2010), p. 411 
- Combined model is a combination of the above mentioned models as presented in figure 4.

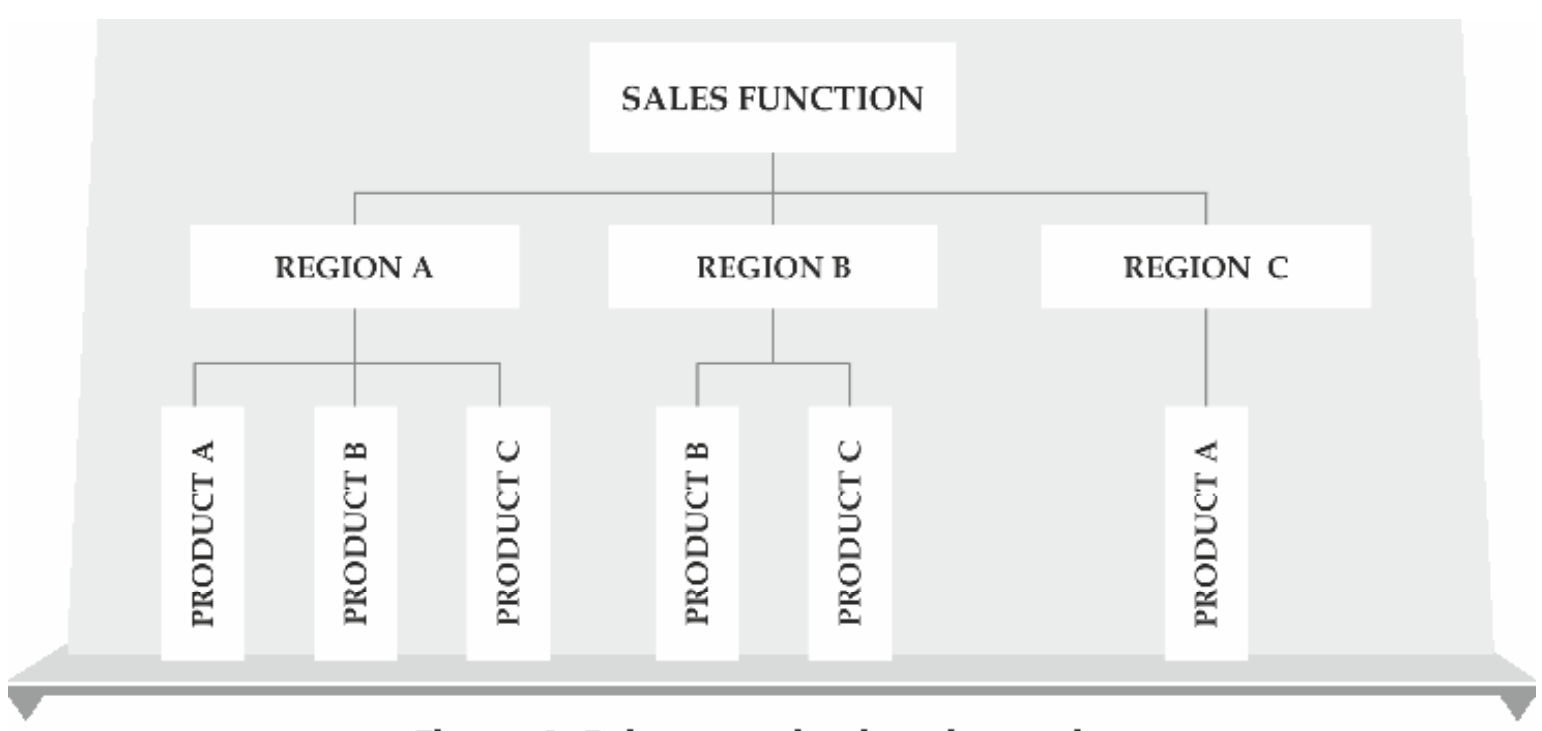

Figure 4. Sales organizations by market

Source: Spaho K., Sales organization and functionality in companies on the industrial market in Bosnia and Herzegovina management research and practice Vol. 2, Iss. 4 (2010), p. 411

The activity of marketing-sales organization is mainly concentrated on sales operations. Marketing support or sales effectiveness are regarded as secondary activity. Such results are presented in the report prepared by Sales Globe (The Sales Leadership Forum \& Sales Globe, 2011, p. 17).

The idea of developing marketing-sale organizations is known in our country on a much smaller scale than the notion of purchase groups. This limited number of such organizations in Poland does not result, however, from a general lack of an interest in such strategy, but has so far been caused by problems in creating and managing such structures. However, one has to take into consideration that there are some established and well-known marketing-sales groups in Poland e.g. the Credit Card Associations of Visa and the MasterCard, agricultural producers' groups or, in the e-commerce sector, the Teleservice Inc. The largest marketing-sales group in Poland is Groupon, which has a $80 \%$ market share, being able to boast above 400000 sold coupons (Marczak 2010. 


\section{Rules of operation of the marketing-sale organizations}

Marketing-sales organizations' goal is to find buyers for their partner's products and to negotiate conditions of sale. Its activity is financed by partners, so it requires a proper, formal organization form. The most frequent legal forms taken on by sales organization are: associations, limited partnerships or stock companies, since those seem to be credible and better acceptable for the long-term cooperation. Sale organizations can also act without forming separate organizational units, for instance, within the framework of project structures (Nawrocka 2010, p. 45). Members of the organizations run their independent, own companies and they have shares in sales organizations. These shares can be disproportionate to their contributions and their value can depend on rules adopted in the group (e.g. depending on entering cooperation, size of the company, its position on the market). Their influence on sale organization's decision making process is usually described in the agreement signed by the association members. Usually the founders of the group hold positions in their authorities and they are also responsible for policy and strategy of the organization. The cooperation of members in group is based on a loyalty and it is growing when their expectations of sale are fulfilled. Coordinating information, product and financial flows is significant for building confidential relationships. The flow must be efficient, in order to correct supply chain activity and become the element of competitive advantage. The key role for ensuring integration process of network of enterprises is played by an integrator. The integrator usually possesses certain distinguishing skills and unique competence and uses the newest concepts of management to synchronize activity of independent firms. Consequently, a special separate unit (called the central unit) should be created in the structure of the network, dealing with putting into practice the purposes agreed on by founders. The growth of efficiency of sale processes of the organizations stems from cause with entrusting with the sequence of all the negotiating, purchase, legal and administrative activities. Joint group actions are linked with the socalled central invoicing, i.e. the central payments management. It means that marketing-sale associations, similarly to purchase groups, are granting the performance guarantee the financial liability towards suppliers (guarantee). Moreover all invoices of members of the organization issued for recipients are passed by the sale association which should be regulated in time from the invoice. In the central invoicing a factoring is usually used, thanks to which a bank is a guarantor and is guaranteeing regular payments for producers. 
Thanks to them the producer has a certainty of receiving payment on time what lets him efficiently plan next supplies and spare the time for checking the credit credibility of its customers. The sale organization should also have funds for current activity. Those founds come from different sources. Those some sale organizations allow to enter their structures free of charge, members of a group generally pay an entrance fee to join. Some organizations have also a significant annual membership fee requirements. Others cover operating expenses and services through charging either solely manufacturers or both manufactures and sales organization members administrative fee, however, these are the administrative fees from manufacturers, which are the main source of group revenue. Additional sources of financing operations of a GPO are:

- central invoicing (one unit makes a transaction on behalf of the whole) and redirecting orders to group members,

- services for members,

- sales of goods,

- and other services for partners,

- founds for industries from EU.

Due to the purpose of the group, a scope and methods of the sale of products of members are essential. Appropriate marketing politics enables members of organizations to become known and to appear permanently in the consumer awareness on new markets. Different promotional treatments provide the recognition of brands of members for the sales organization in the region or the country in the similar rank as the brands of concerns. Appropriately promoted brands provide the strong position for members on the market, allow them to be identified and at the same time enable to pursue the own strategy supported by the proper advertisement.

Contemporary marketing-sale organizations do not deal only with the organization of sale of member's products, but also provide a professional marketing support. They often create their own brand to promote it against competitors, for especially large concerns. Organizations' brands are important tool supporting activity of the organization's members, because those brands in combination with the superior brand enable to conduct marketing, attractive for customers as well as are ensuring the higher consumer loyalty (Knoben 2013, http://www.een.org.pl/index.php/rynek-wewnetrzny---spis/articles/zwiazkizakupowo-marketingowe-w-niemczech.html, 19.04.2016 - access date).

Increasing the development of the group the scope of services offered is also wider. Some sale organizations, especially the ones bigger, are maintaining

The marketing-sales organizations as the way of internationalizing of the small and medium enterprises 
also own warehouses, where there are stored finished products of producers for a quick respond for needs of key recipients. Depending on the industry, for which goods are being stored, logistic magazines are useful both in the fight for the priority in export, as well as in everyday supplying recipients. Some organization are offering a range of training programs for its members and their employees. Very important in this field of activity are communication platforms, which helps member to exchange of experiences or discuss day-today problems. Organizations also try to provide other support of members; which depends on the specific needs e.g. granting guarantees or taking members recommendations.

The accession to the sale organization is also possible during its activity, however such applicant must accept existing principles and procedures of the group. The first accession payment is often also higher than, the payment of founders of the group. Generally the organization accepts the new producer if profile of applicant's activity, its financial position and qualities of products meet the standards of the organization. Getting the approval of the central unit and making the preliminary payment are a sufficient condition in order to become the member of organization and be in the list of suppliers license by the association.

Sales organizations are the most popular in the United States of America, where as a result of their activity firms can reach $22 \%$ growth of export in first years, even $42 \%$ next one. (TinderBox 2013 Report, p. 2). According S. Martin's research (Martin, 2014, pp1020) sales organization's effectiveness depends on their life cycle, the earliest stage of activity the better effectiveness. In Europe there are a lot of well prospering sales organization in Germany, where there are 320 such organizations, which group over 230 thousand independent businesses of the different sectors. The organizations employ 10 million employees, thanks to which annual turnovers of companies are circa 500 million EUR, which is the $18 \%$ of GDP of the Federal Republic. Foreign producers wanting to put their products onto the German market are not able to miss powerful sales organizations in this country (Knoben, Sawinski, 2013, http://www.een.org.pl/index.php/rynekwewnetrzny---spis/articles/zwiazki-zakupowo-marketingowe-w-niemczech. html, 19.04.2016 - access date). According to above mention data such concepts is possible to be successfully implemented in other Western European countries, where entry the foreign market requires special competence as knowledge and experience in sale on the market and expected cost of entry is significant. It is a success key of this undertaking. 


\section{Marketing-sale organization and the internationalization strategy - opportunities and threats}

It is obvious that participation in sales organizations, just as every solution, has both advantages and disadvantages. Presented concept of building cooperation of enterprises is one of alternatives of the market development strategy for Polish SME. They can exploit it or act on their own way on foreign markets consuming time and resources. Additionally market development strategy needs proper knowledge of culture and legal circumstances of transactions. Those factors are not the strongest side of SME. Individual activity of enterprises on foreign market often does not give expected incomes e.g. participating in an exhibitions or other trade fair small firm usually gets client for one-time transactions and building long-term, profitable cooperation is a problem. A PARP report, showing that SME reach growth of export c 35\% but only the $5 \%$ from them is keeping the cooperation with customers they contacted during exhibition (Dąbrowska, Dana and other 2015, p. 27).

According to above presented results joining the marketing-sale organizations on foreign markets seems to be attractive solution for Polish SME, because in spite of a long-time preparatory period, lets increasing quantity of customers and in consequence company income. Other crucial advantage for SME is keeping timely and stable payments, thanks to the central invoicing and the factoring accompanying it. These determinants cause, that the entry markets risk is reduced. Because the sale group is taking over costs of the market penetration, finding credible representatives or distributors to itself and based on its possibilities and signed agreements provides the annual volume for the sale. Sales organizations, specialized on the foreign market, cover the costs of the entry, finding credible representatives and distributors and based on its market position and signed agreements provides the annual volume for the sale, so other benefits of being a member of a the group are (Piorunowska-Kokoszko, 2015, pp. 56-70):

- keeping the independence of business,

- access to new customers of goods and services thanks to contacts of the group,

- possibility of the extension of the current offer,

- lowering costs of marketing and sales activity (from a few up to a dozen percent, which contributed to the improvement in the profitability of the company),

- minimization of the risk of delivery of goods as a result of the fact that the cooperation takes place with the distributors whose reliability has been checked by the group, 
- the improvement of competitiveness,

- time savings on building relationships with the customers (a group can save a company's time and effort spent on negotiations by means of making available to it an advantageous contract),

- and finally sales organization provides its members with access to specialists (who are obliged to help in case of trouble, train in sales and business activities, and supply them with both product information and standardization, i.e., comparison shopping and best combinations of cost and quality for demanded products).

The accession to the group brings also certain threats. The organizations often in negotiations use straights reasoning: the higher takeover is proposed, the customer will pay smaller price. A turnover is supposed to compensate for the fair price fully. Causing the growth of rotations at the lower profit does not cause the rise in incomes of the company at all. The rise in volume turnovers causes behind itself you will pull indirect costs so as the logistics or the in-house service of the buying decision process. The takeover of considerable capital value at the narrow margin is supporting the low financial stability. Such situation is not a comfortable or safe for the current and future activity of enterprise. Classic example of such solution is collective contracts involving forces and resources not inappropriate to benefits. To prevent interest of producer it is necessary to establish clear establishing assumptions of the sale e.g. the minimum price of the sale covering all costs of consisted entities. Other disadvantages of using sales organizations can reduce the amount of control the sale's department of an enterprise has over its sales decisions.

In Poland the sales organizations are an innovative solution which is being initiated by companies from Western Europe. Foreign sale organizations are seeking new clients for themselves because of their recipients, who often recognize Polish products to be attractive in terms of the ratio of the low price to the best quality and want to include them in their sale offer. However appearing offers of the cooperation are not met with great interest. Polish SME do not have knowledge of sales organizations activity that is why they do not trust such cooperation, which are restrictions for themselves. Sales organization activity is also a little problematic, because of its lack of national legal regulations which would allow to keep financial regime and forecast trends. The other, but essential barrier for joining sales organizations is a level of their financial participation required by the group (required fees and the commission of sale for central unit). EU programs including financing cooperation is eliminating this weakness and causes, that more and more owners of companies appear on meetings initiated 
by supporting institutions (PARP). Those owners of SME, who have experience and knowledge about costs of entry to foreign markets are interested in the new solution, which seems to be attractive for them. It is appropriate statement, that sales organizations become one of the element of Polish SME supply chain and n't will not remain only a German phenomenon.

\section{Conclusions}

Nowadays the globalization causes, that if the companies entry foreign markets they must accept its conditions and culture. Sometimes it can require products modification or a model of management. Today it is already obvious, that the internationalization is becoming a part of the strategy, so more and more of SME put some effort into success of this strategy. The appropriate decision about the way has influence on the future result of the undertaking. However every situation is different, a lot is depends on market type, on the form of entry or internal conditions of the company. The most important thing is to have ability to identify the crucial determinants for internationalizing, as well as analyze possible opportunities and threats. AMR Research amongst 133 American managers gave the ground for expressing the conclusion that cooperation with business partners and entering into a contract with recipients are the most effective way of reducing market turbulences, danger of disruptions and unpredictable events (AMR Research, 2009). Running a sales organization successfully is a challenge, so joining the sales organizations creates possibilities of exploiting experience of other companies and having access to new delivery channels.

I can sum, that from one hand marketing-sales organizations are able to increase the value of sale in the foreign market thanks to proper accesses to distribution channels or directly to business partners. On the other hand the costs of group activity and promotion are seemed to be a barrier for Polish SME. In spite of those costs, Polish entrepreneurs do not know the rules of marketing-sales organizations, which causes that they treat such decision as very risky and decide to implement internationalization strategy themselves. Because of innovative character of this solution, managers find it to be very controversial. The EU support also does not eliminate the level of risk, that is why the marketing- sales organizations are not present in the structure of SME's supply chains.

I think that enterprises which are not open to new opportunities, are giving up from the cooperation with other companies are not only limited 
their development, but potential chances to get profit from the market and consequently their competiveness. Giving the cooperation up must be conscious action, because this decision as every one, can bring expected benefits or be difficult to reconstruct in the future.

\section{Summary}

Themarketing-sales organizations as theway of internationalizing of the small and medium enterprises

The internationalization is becoming a part of company's strategy, requiring some effort for getting its success. The present article is aimed at showing that joining the sale group is one of many ways of internationalizing activity for small and medium enterprises. The article presents the roles of sales group activity, its typical structure and opportunities and threats for its functioning. Based on collected data it was pointed, that companies, especially SME should analyze perspective for joining the sale group in their supply chain or seek for other forms of cooperation supporting their foreign market entry. Cooperation allows in relatively short time to achieve first results. Resignation of cooperation should be a conscious decision of management. Such decision, as every one, can bring expected benefits or be difficult to reconstruct it in the future.

Keywords: sales organizations, internationalization, market development.

\section{Streszczenie}

Grupa marketingowo-sprzedażowa jako sposób umiędzynarodowienia działalności małych i średnich przedsiębiorstw

Internacjonalizacja staje się częścią strategii coraz większej liczby MSP, które muszą włożyć ogromny wysiłek w jej powodzenie. Niniejszy artykuł ma na celu wskazanie, iż przyłączenie się do grupy sprzedażowej jest dla małych i średnich przedsiębiorstw jednym ze sposobów umiędzynarodowienia swojej działalności. W opracowaniu zaprezentowano koncepcję działania grupy marketingowo-sprzedażowej, jej strukturę oraz szanse i zagrożenia dla jej funkcjonowania. W oparciu o zebrane dane wskazano, iż w dobie globalizacji, że MSP winny rozważać włączenie grupy sprzedażowej do swojego łańcucha dostaw lub poszukiwać innych 
form kooperacji ułatwiających im wejście na rynki zagraniczne. Kooperacjapozwalawstosunkowokrótkimczasieosiągnąćpierwsze wyniki. Odrzucenie współpracy powinno być zatem świadomym i przemyślanym działaniem, gdyż ta, jak każda decyzja może przynieść oczekiwane korzyści, ale może być też ograniczeniem trudnym do odtworzenia w przyszłości.

\section{Słowa}

kluczowe: grupa sprzedażowa, internacjonalizacja, rozwój rynku.

\section{References}

1. Aluchna M., Cygler J., Materna G., Witek-Hajduk M. K., Marciszewska E., Kooperacja przedsiębiorstw $w$ dobie globalizacji: Wyzwania strategiczne, Wolters Kluwer 2011.

2. AMR Research(2009), Supply Chain Risk 2008-2009.

3. Bartkowiak P, Domański J. (2012) Bartkowiak P., Domański J., Szpitalne Grupy Zakupowe w kształtowaniu łańcucha wartości na rynku ustug szpitalnych [in:] A. Marjański (ed.), Przedsiębiorczy Menedżer Przedsiębiorczej Organizacji, Nowoczesne tendencje w nauce oraz w praktyce organizacji i zarządzania, Przedsiębiorczość i Zarządzanie, tom XIV, Iss. 3.

4. Czakon W. (2010), Hipoteza bliskości, „Przegląd organizacji”, 2010 No. 9, pp. 16-21.

5. Dąbrowska E., Dana P., Walczak-Gomuła M., Baryła-Zapała E., Czerniec E, (2015), Badanie ewaluacyjne; Ocena efektów realizacji projektu systemowego pn. "Promocja polskiej gospodarki na rynkach międzynarodowych" w ramach POIG, ASM, Kutno.

6. Eksperci: mate i średnie firmy wymagaja wsparcia, by zawojować świat, http:// biznes.pl/firma/eksperci-male-i-srednie-firmy-wymagaja-wsparcia-byzawojowac-swiat/th5r7h (10.04.2016 - access date).

7. Gajowiak M. (2014), Małe i średnie przedsiębiorstwa przetwórstwa żywnościowego $z$ wybranych powiatów Wielkopolski $w$ procesie internacjonalizacji, Economics and Management 2, pp.108-120.

8. Kaszyński W., Federowski J., Szpitalne grupy zakupowe. Wspólnymi siłami, Menedżer zdrowia, grudzień- styczeń 10/2011.

9. Knoben H., Sawinski M. (2014), Zwiazki zakupowo-marketingowe w Niemczech, http://www.een.org.pl/index.php/rynek-wewnetrzny ---spis/articles / zwiazki-zakupowo-marketingowe-w-niemczech.html (19.04.2016 - access date).

10. Koniewski M., Krupnik S., Skórska P., Turek K, Geodeck T. (2015), Raport PARP, BAROMETR INNOWACYJNOŚCI, Konsorcjum Centrum Ewaluacji i Analiz Polityk Publicznych, Uniwersytet Jagielloński oraz 
EGO - Evaluation for Government Organizations, www.badania.parp. gov.pl/images/badania/Raport_Barometr_netto_POIG.pdf (17.04.2016 access date).

11. Lichtarski J. (2007), Podstawy nauk o przedsiębiorstwie, Wydawnictwo Akademii Ekonomicznej we Wrocławiu, Wrocław.

12. Marczak G. (2010), Groupon - 80\% rynku w Polsce, 400000 sprzedanych kuponów. Nowym serwisom na razie dziękujemy, www. antyweb.pl/groupon80-rynku-w-polsce-400-000-sprzedanych-kuponow-nowym-serwisomna-razie-dziekujemy/\#(20.04.2016 - access date).

13. Martin S. (2014), Why Sales Organizations Fail, Harvard Business Review, $30 / 01 / 2014$.

14. Mazur J. (2011), Wspótpraca przedsiębiorstw w teorii i praktyce polskiej, [in:] Zeszyty Naukowe Kolegium Gospodarki Światowej, Zeszyt nr 32, Szkoła Główna Handlowa, Warszawa.

15. Nawrocka (2010), Grupy zakupowe- szansa na tańsza energię, Nowa Energia $4(15) / 2010$

16. NiewinowskaM.(2015),Funduszeunijne:Eksportpodopiekuńczymiskrzydłami, http://serwisy.gazetaprawna.pl/msp/artykuly/861256,funduszeunijne-eksport-pod-opiekunczymi-skrzydlami.html (15.04.2016 - access date).

17. Nieżurawski L. (2010), Formy zaangażowania przedsiębiorstw sektora budowlanego na rynku międzynarodowym, [in:] Koncepcje i metody zarządzania strategicznego oraz nadzoru korporacyjnego. Doświadczenia i wyzwania, Zakrzewska-Bielawska A. (ed.), Wydawnictwo C.H. Beck, Warszawa.

18. Nowak D. (2012), Zarządzanie międzyorganizacyjnymi relacjami kooperacyjnymi $w$ przedsiębiorstwach przemystowych, Wydawnictwo Uniwersytetu Ekonomicznego w Poznaniu, Poznań.

19. Piorunowska-Kokoszko, J. (2015), Group Purchasing Organization (GPO) as a Means of Business Costs Savings, Journal of Positive Management 6.1, pp. 56-70.

20. Raport TinderBox (2013), Sales Proposal Effectiveness in B2B Sales Organizations, Sales Management Association, Boston.

21. Rozporządzenie Komisji Europejskiej nr 651/2014 z dnia 17 czerwca 2014 r. http:/ / ec.europa.eu/enterprise/policies/sme/files/sme_definition/ sme_user_guide_pl.pdf (07.04.2015 - access date).

22. Sawyers A. (2015), Big, medium-sized dealership groups grow, Automative News, Suplement, 16 marca 2015, www.autonews.com/assets/PDF/ CA98762313.PDF (27.10.2016. - access date).

23. Spaho K. (2010), Sales organization and functionality in companies on the industrial market in Bosnia and Herzegovina, Management research and practice ,Vol. 2, Iss. 4 (2010). 
24. Structuring Sales Operations, Choosing the Right Structure for Your Organziation (2011), The Sales Leadership Forum \& Sales Globe, Atlanta, Geogria.

25. Wilson A. (2005), Building a Successful Selling Organization: The Critical Path to Extraordinary Results, iUniverse.

26. Wrońska E.M. (2012), Teoria kosztów transakcyjnych a grupy zakupowe, A n n a 1 e s Universitatis Mariae Curie-Skłodowska, Lublin-Polonia, Vol. XLVI, 1.

27. www.autonews.com/assets/PDF/CA98762313.PDF (27.10.2016 - access date).

28. www.gus.pl (11.04.2016 - access date).

29. www.poland-export.pl/articles/3983 (10.04.2016 - access date).

30. Wyżnikiewicz B. (2013), Polskie MSP na drodze ku nowoczesności, Raport z wyników badania przygotowanego przez Konfederację Lewiatan, IBnGR, Warszawa. 